\title{
STEM ROT OF GROUNDNUT INCITED BY SCLEROTIUM ROLFSII SACC. AND IT'S MANAGEMENT - A REVIEW
}

\author{
ATLA RANGA RANI \\ Research Scholar, Department of Plant Pathology, \\ S.V. Agricultural College, Tirupati, Andhra Pradesh, India
}

\begin{abstract}
Groundnut (Arachis hypogaea L.) is an important oilseed crop. The low productivity in groundnut is attributed to many production constraints. Among these, biotic factors, particularly diseases play a major role in limiting the yield of groundnut. It is most affected with the pathogen Sclerotium rolfsii sac, which is a soil-borne pathogen and causes disease in different crops including peanut. Biological control is an alternate source by introducing soil borne pathogens, which helps in suppressing the disease. While in combination with biocontrol agents and fungicides for seed treatment, it was effective in suppressing the pathogen, besides reducing the environmental hazards and cost of cultivation. This paper reviews the literature on Sclerotium rolfsii, inducing stem rot disease and its management.

KEYWORDS: Groundnut, Sclerotium Rolfsii, Biological Control \& Management
\end{abstract}

Received: Apr 18, 2017; Accepted: May 20, 2017; Published: May 31, 2017; Paper Id.: IJASRJUN201742

\section{INTRODUCTION}

Groundnut is called as the 'King' of oilseeds. It is one of the most important food and cash crops of our country. While being a valuable source of all the nutrients, it is a low priced commodity. Groundnut is also called as wonder nut and poor men's cashew nut. Groundnut is one of the most important cash crops of our country. It is a low priced commodity, but a valuable source of all the nutrients. Groundnut is grown on 26.4 million ha worldwide with a total production of 37.1 million metric $\mathrm{t}$ and an average productivity of 1.4 metric $\mathrm{t} / \mathrm{ha}$. India occupies the first place, both in regard to the area and the production in the world. In India groundnut is mostly grown in 5 states viz. Gujarat, Andhra Pradesh, Tamil Nadu, Karnataka and Maharashtra, which accounts for 80 percent of the total area and production of groundnut (Reddy, 1992). Groundnut seeds are valued for oil (40-48\%) and protein $(22-26 \%)$ also contain carbohydrate $(26 \%)$ fat $(3 \%)$ and high calcium, thiamine and niacin contents, which make a substantial contribution of protein for human and animal nutrition (Maiti et al., 1991). The major production constraints are unreliable and erratic distribution of rainfall and appearance of unpredictable diseases and pests accounting for low productivity. Diseases are one of the major constraints responsible for the low productivity. Several fungal species have been reported to be associated with groundnut seed. Among the different pathogens attacking the crop, Aspergillus Niger, Aspergillus flavus, Rhizoctonia bataticola and Sclerotium rolfsii are the most important fungi causing seed and seedling rots and stem rot diseases. Among the soil-borne fungal diseases, stem rot caused by Sclerotium rolfsii is a potential threat to successful groundnut cultivation. This disease causes severe damage near maturity and yield losses over 25\% have been reported by Maya and Datar (1988). The Sclerotium rolfsii has an extensive host range, prolific growth rate and ability to produce large numbers of sclerotia that may persist in soil for several years (Punja, 1985). In India, the disease is more severe in Maharashtra, Gujarat, 
Madhya Pradesh, Andhra Pradesh, Orissa and Tamil Nadu (Krishnakanth et al., 1999). The stem rot caused by Sclerotium rolfsii Sacc. has been a major problem in groundnut growing regions. This paper reviews the literature on Sclerotium rolfsii inducing stem rot disease and its management.

\section{STEM ROT PATHOGEN}

The pathogen Sclerotium rolfsii Sacc., is a soil borne pathogen that commonly occurs in the tropics, sub-tropics and other warm temperate regions of the world, causing root rot, stem rot, wilt and foot rot on more than 500 plant species, including almost all the agricultural and horticultural crops (Domsch et al., 1980; Farr et al., 1989). This was first time reported by Rolfs (1892) as a cause of tomato blight in Florida. Later, Saccardo (1911) named the fungus as $S$. rolfsii sp.

\section{MORPHOLOGY OF THE SCLEROTIUM ROLFSII}

Sclerotia initially white in colour, later it becomes light brown to dark brown at maturity and they are sub sphere, the surface finely wrinkled, sometimes flattened (Subramanian, 1964 and Mehan, 1995). This pathogen Sclerotium rolfsii forms brown sclerosis, which is very well organized, compact structures, built of three layers, the rind, composed of empty melanised cells; the cortex cells, filled with vesicles and the medulla (Chet, 1975). Sclerotia were superficial on the affected part, spherical or ellipsoidal and measured $0.5 \mathrm{~mm}$ to $2.5 \mathrm{~mm}$ in diameter. Non germinated sclerotia become soft and broke easily. Maceration of cortical cells was common. A bacterium like organism was consistently associated with the ruptured and macerated slot (Narsimha Rao, 2000).

\section{SYMPTOMATOLOGY}

Symptoms are typified by the development of white fungal thread over the affected plant tissue. The disease starts with pre emergence rot of seeds characterized by rotten and softened seeds, which are covered by the white profuse mycelial growth of fungus. The pathogen attacks the germinated seedlings and causes wilt. In young seedling, a sheath of white muslin develops on or near the soil line around the affected area of the stem, which later turned to dark brown and small round bodies about the size of mustard like sclerotia seed are produced on the surface of infected tissue and the adjacent soil. Abundant sclerotia initially white and later turning brown, develop in the infected area. Young plants may be completely girdled and killed, a condition is known as foot rot. The pathogen attacks all the parts of the plant, but stem infection is most common and destructive yellowing and wilting of branches near the base is the first symptom.

Mehrotra and Aneja, (1990) noticed the cortical decay of stem base at ground level and appearance of conspicuous white muslin, which extended into the soil and on organic debris. The mycelial mat may extend several centimeters up to the stem above the soil line. Pods and kernels may be affected, on young pods orange, yellow or light tan lesions develop, which darken to brown or black on older pods. In advanced stages of decay, shriveled and covered with wisps of mycelium. The fungus can also cause blue damage (bluish black discoloration of testa) as a result of oxalic acid production. Whitish growth inside shell covers the surface of kernels (Frealin, 1973).

\section{ISOLATION AND MAINTENANCE OF THE PATHOGEN}

Sclerotium rolfsii was isolated from different plants viz., diseased seeds and seedlings (Rama Rao and Usharaja, 1980. Uma Singh and Thapliyal, 1998. Rajeevpant and Mukopadhyay, 2001), stem (Kajal Kumar and Chitreswar Sen, 2000), collar region (Ansari and Agnihotri, 2000., Narasimha Rao et al., 2004), root (Srikanta Das and Raj, 1995., Harinath Naidu, 2000 and for et al., 2005), tubers, crown, leaves and pods (Gupta and Ashu Sharma, 2004). Potato Dextrose Agar 
(PDA) was found to be the best supporting medium for S. rolfsii (Harinath Naidu, 2000, Gupta and Ashu Sharma, 2004., Gaur et al., 2005 and Raoof et al., 2006). S. rolfsii can also be maintained on potato sucrose agar medium (Ramarao and Usharaja, 1980).

\section{MASS MULTIPLICATION OF SCLEROTIUM ROLFSII}

The pathogen Sclerotium rolfsii was mass multiplied on sterilized sorghum grains presoaked overnight in 2 percent sucrose solution (Upadhyaya and Mukhopadhyay, 1986). Different substrate has been used by different workers for mass multiplication of $S$. rolfsii in vitro such as sterilized sorghum grains (Uma Maheswari et al., 2002; Patibanda et al. 2002), wet wheat bran: vermiculate (1:1 w/w) (Prasad et al., 1999) and sand maize meal medium (Rajani et al. 2006; Anahosur 2001; Dutt and Das, 2002; Rao et al. 2004).

\section{PROOVING PATHOGENECITY}

Kajal Kumar and Chitreswar Sen, (2000) isolated Sclerotium rolfsii from the roots of the affected plants. Inoculations with this isolate produced hundred per cent infection on Groundnut plants, while the control plants remained healthy. Artificial inoculation of the plants with the pathogen was done by different methods. Soil inoculation by the pathogen was studied by several workers. Vinod Dange (2006), Rajani et al. (2006) Seedling root dip inoculum was used to induce sclerotial wilt in bell pepper (Anitha Chowdary, 1997).

\section{IN VITRO EVALUATION OF FUNGICIDES, HERBICIDES, BOTANICALS AND BIO-AGENTS AGAINST S. ROLFSII}

\section{Effect of Fungicides against S. Rolfsii under in Vitro Conditions}

Sclerotial wilt is a serious menace causing complete death of seedling and mature plant. Numerous chemicals inhibited the sclerotial germination and mycelia growth of $S$. rolfsii and efficiently controlled the disease caused by the pathogen on various crops. carboxin was effective to inhibit S. rolfsii (Punja., 1982; Patibanda et al., 2002; Rakholia and Jadeja., 2010). The complete mycelia growth inhibition of $S$. rolfsii was reported with saff,tebuconazole, captan, calixin, ril f004, tilt, idofil M-45, contaf, mancozeb, hinosan, thiram, antracol., benlate and manzate (Bhat and Srivastava, 2003; Rout et al., 2006; Gupta and Sharma 2004; Sunkad, 2012: Kapadiya et al., 2013). Pranab Dutta and Das (2002) studied in vitro efficacy of thiram and mancozeb at $0.1 \%$ concentration against tomato isolate of $S$. rolfsii and reported that thiram had inhibited $70.3 \%$ of mycelial growth and $96.5 \%$ of sclerotial production of S. rolfsii. Narayana Bhat and Srivastava (2003) evaluated in vitro efficacy of captain, thiophanate-methyl and propiconazole at 250, 500 and 1000 ppm concentrations against $S$. rolfsii. Torray et al. (2007) reported that tebuconazole and carboxin gave cent per cent growth inhibition of $S$. rolfsii. Johnson et al. (2008) reported the inhibition of S. rolfsii pathogen with Hexaconazole and Propiconazole at $0.1 \%$ and $0.2 \%$. Radhaiah, (2012) also reported that mancozeb @ 0.2\% completely suppressed the pathogen. Madhavi (2011MADHURI) reported the in vitro evaluation of nine fungicides by poison food technique showed that tebuconazole and combination of carbendazim+mancozeb were effective in inhibiting the mycelial growth (94.1\%) followed by difenconazole $(93.3 \%)$.

\section{In Vitro Evaluation of Herbicides against Sclerotium Rolfsii}

The effect of ten herbicides incorporated into PDA in 50, 100 and $500 \mu \mathrm{g} \mathrm{ml-1} \mathrm{reduced} \mathrm{the} \mathrm{mycelial} \mathrm{growth} \mathrm{and}$ sclerotial formation of S. rolfsii, M. phaseolina and F. oxysporum under in vitro by Vyas et al. (1986a). Tripathi et al. (1988) reported that herbicides 2, 4-D and fluchloralin drastically inhibited the growth of S. rolfsii and R. bataticola. The 
effects of acetochlor, imazethapyr, metachlor, pendimethalin, trifluralin and mixture acetochlor and imazethapyr on the production and viability of $S$. rolfsii sclerotia were evaluated in vitro by Pastor and March (1999). Trifluralin and pendimethalin were the most efficient compounds, because they notably reduced the production of viable sclerotia. Madhuri and Narayan Reddy (2013) evaluated eight herbicides tested for their efficacy on S. rolfsii by poisoned food technique and found that oxyflourfen, alachlor, quizalofop-p-ethyl and 2, 4-D sodium salt completely inhibited the growth of S. rolfsii. Madhuri and Sagar (2016) quizalofop-p-ethyl showed cent per cent inhibition followed by pendimethalin $(92.22 \%)$, imazethapyr $(68.88 \%)$ and oxyflourfen $(51.85 \%)$.

\section{Effect of Botanicals against S. Rolfsii}

Dutta and Deb (1986) studied the effect of organic and inorganic amendments on the soil and Rhizosphere microflora in relation to the biology and control of Sclerotium rolfsii. They reported that, leaf extract of Eupatorium adenophorum reduced the pathogen population in the rhizosphere. Singh et al. (1989) reported that, out of six plant oils tested against $S$. rolfsii, leaf oil of Azadirachta indica was found most effective, followed by that from Eucalyptus globules and Ocimum canum. Singh and Dwivedi (1990) reported that, the viability of sclerosis was reduced when treated with neem oil. Seshakiran (2002) reported that, Eupatorium odoralum L., C. occidentalis and Azadirachta indica were highly antifungal to mycelial growth of S. rolfsii. However, root extract of Pathenium hysterophorus L. Exhibited maximum inhibition of mycelial growth of $S$. rolfsii.

\section{In Vitro Evaluation of Bioagents against S. Rolfsii}

Garrett (1956) defined the biological control of plant diseases as "any condition under which, survival and activity of a pathogen are reduced through the agency of any living organisms". McMilan et al. (1949) suggested that, reduction in germinability of sclerotia was due to the action of antagonistic organisms. Laha et al. (1996) reported that sclerotial viability of $S$. rolfsii causing cotton wilt was reduced when immersed in $P$. fluorescens cell suspension or in a cell free culture filtrate. Narasimha Rao (2000) stated that, biological control is an eco-friendly and effective means of reducing the disease through potential antagonistic micro-organisms. Charitha Devi and Reddy (2003) isolated 5 isolates of Trichoderma spp and Pseudomonas sp, against Sclerotium rolfsii causing root rot of groundnut, and reported that T. harzianum showed maximum (66.6\%) inhibition of Sclerotium rolfsii. Manjula (2004) reported that T. viride pq 1 produced extracellular chitinase and parasitized the mycelium of S.rolfsii. Manyar et al.,(2004) studied Fluorescent Pseudomonas sp. Having the ability to produce the pyoveridine type of siderophores under low iron stores (up to 10 micro $\mathrm{M}$ iron in the succinate medium) and reported that purified siderophores and Pseudomonas culture have good antifungal activity against the plant deleterious fungi, viz, Aspergillus Niger, Aspergillus flavus, Aspergillus oryzae, Fusarium oxysporum, and Sclerotium rolfsii. The principle mechanisms for control of plant pathogens by Trichoderma spp. Include mycoparasitism, antibiosis and competition for resources and space (Wood and Tveit, 1955). Varadharajan Karthikeyana (2007) reported Tv1 of T. viride caused $69.40 \%$ inhibition of the mycelial growth of the pathogen. Rakh (2011) isolated 11 Pseudomonas spp., from rhizospheric soil, were evaluated for their antagonistic activity against Sclerotium rolfsii. A soil bacterium identified as, Pseudomonas cf. monteilii 9, showed highest antagonistic activity against the pathogen Sclerotium rolfsii. He reported, the Pseudomonas cf. monteilii 9 inhibited the Sclerotium rolfsii to up $94 \%$ in terms of dry weight. Chanutsa et al. (2014) reported 100per cent inhibition in the growth of $S$. rolfsii with culture filtrate of P. Florescence. Deepika et al. (2014) reported that the culture filtrate of Trichoderma harzianum PBT 23 at 50 per cent was found significantly effective in inhibiting the mycelia growth of $S$. sclerotiorum, $R$. solani, $S$. rolfsii, F. oxysporium B. ceneria at 
a range of $20.6-48.9$ per cent.

\section{Endophytic Microorganisms in Biological Control}

Endophytic organisms are those that colonize the plant internal tissue showing no external sign of infection or negative effect on their host (Schulz and Boyle, 2006). Endophytic bacteria must also be compatible with host plants and able to colonize the tissues of the host plants without being recognized as pathogens (Rosenbleuth and Martinez-Romero, 2006). Exploitation of endophyte - plant interactions can result in the promotion of plant health, and can play a significant role in low-input sustainable agriculture applications for both food and non-food crops.

\section{Antagonistic Activity of Root Endophytes}

Endophytic bacteria must also be compatible with host plants and able to colonize the tissues of the host plants, without being recognized as pathogens (Rosenbleuth and Martinez-Romero, 2006). Basically, being saprophytes and with the additional ability of entering the plant as endophyte, mechanisms of antagonism appeared to remain same with that of rhizosphere antagonistic microflora. Ziedan (2006) isolated root endophytes from peanut healthy roots and found that Bacillus subtilis abundantly colonized peanut root than $P$. fluorescens, and reported that effectively controls the root and pod rot diseases. Durga Prasad et al. (2008) isolated endophytic Trichoderma GSEF3 and root endophytic bacteria GRE 29 which showed higher inhibition per cent on $S$. rolfsii growth in vitro. Adhilakshmi et al. (2013) reported that five isolates of actinomycetes (CBE, MDU, PDK, ANR and SA) out of 30 were found effective in inhibiting the mycelial growth of $S$. rolfsii the stem rot pathogen of groundnut.

\section{IN VIVO STUDIES}

For soil borne plant pathogenic fungi, seed treatment and soil applications have been widely used. A brief review of the work done is presented herewith.

\section{Seed Treatment of Biocontrol Agents}

Seed treatment of the biological control agent helps the antagonist to grow along with the root, and occupy the rhizosphere with the advantage of being the primary colonizer. Several reports were published on the use of seed treatment method in biological control. Harman et al. (1998) suggested the application of Trichoderma or Gliocladium to seed as an alternative approach to introducing them into the soil. Podile and Dube (1988) reported that seed coating with $P$. fluoroscens (PN-3) controlled stem rot pathogens of peanut (S. rolfsii and R. solani) in pot experiments. Muthamilan and

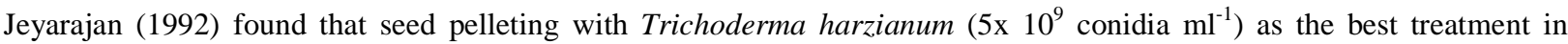
controlling root rot caused by S. rolfsii. Bhatia et al. (2005) reported that fluorescent Pseudomonas PS-I and PS-II coated seed sown in S. rolfsii infected soil significantly increased seed germination by 13.1 and 8.5 per cent respectively as compared to control. Singh et al. (2013) selected Trichoderma spp. and Pseudomonas spp. for seed and seedling treatment in tomato, to assess the synergistic effect of compatible isolates for plant growth promotion and management of $S$. rolfsii. He concluded that the application of a consortium of compatible bioagents enhanced the plant growth and biological control of the pathogen in contrast to treatment with single bioagent. Belkar et al. (2013) reported that the seed treatment with Pseudomonas fluorescens @10g/kg of seed+Bradyrhizobium japonicum @ 20g/kg of seed + Pseudomonas striata@ $20 \mathrm{~g} / \mathrm{kg}$ of seed with minimum stem rot incidence, i.e. $8.86 \%, 13.33 \%, 20.00 \%$ at 20 DAS and $17.73 \%, 33.33 \%$ and $40.00 \%$ of flowering, respectively. 


\section{Soil Application of Biocontrol Agents}

While seed treatment gives the advantage of antagonist being the first colonizer of the rhizosphere, soil application has the advantage of inhibiting the pathogen even away from the rhizosphere. Further, as the quantity of inoculum required for soil application is high, in general, better management is obtained with soil application strategy. Soil application of $P$. Fluorescence was effective in controlling collar rot of groundnut incited by S. rolfsii (Patil et al., 1998). Soil application of T. harzianum @ $60 \mathrm{~g} \mathrm{~kg}^{-1}$ of natural soil reduced stem rot of groundnut caused by $S$. Roofs up to 83 per cent (Biswas and Sen 2000). Biswas et al. (2000) observed that application of T. harzianum inoculum to soil and seed dressing at the time of sowing in the pots exhibited percent disease reduction through seed dressing from 33 to $50 \%$, and through direct soil application it was 72 to $83 \%$. Sclerotium wilt of groundnut caused by $S$. rolfsii was effectively reduced to 92.58 per cent, when T. harzianum was applied @ $10 \mathrm{~g}, \mathrm{~kg}^{-1}$ soil (Patibanda et al., 2002). Soil application of T. harzianum $(H)$ inoculum was superior in reducing the percentage disease incidence and increased shoot length $(24 \mathrm{~g})$, root length (17.0), and yield $1509 \mathrm{~kg}$ ha-1 against root rot of groundnut caused by Sclerotium rolfsii, Saralamma and Vithal Reddy (2003)

\section{INTEGRATED MANAGEMENT OF STEM ROT OF GROUNDNUT CAUSED BY S. ROLFSII}

Asghari and Mayee (1991), reported that, application of T. harzianum inoculum and soil drenching with 0.2 per cent carbendazim reduced the stem rot of groundnut caused by 44-60 percent, and increased the pod yields by $17-47 \%$. Muthamilan and Jeyarajan (1996) found in their glass house studies that, integration of seed treatment with T. harzianum, Rhizobium $+T$. harzianum inoculum added to soil 6 days after sowing plus carbendizam $(0.1 \%)$ soil drenching on 30 DAS was more effective in reducing root-rot of groundnut caused by S. rolfsii. Patibanda et al. (2002) observed effective control of sclerotium wilt of groundnut caused by $S$. rolfsii, when seed coating with thiram $(0.1 \%)$ was integrated with soil applicaton of T. harzianum @ $4 \mathrm{~g} \mathrm{~kg}^{-1}$ soil. Vanitha and Suresh (2002) conducted a study to investigate efficacy of biological control agents and organic amendments in controlling collar rot of brinjal caused by Sclerotium rolfsii, where Trichoderma viridae + FYM + dry adathoda leaf powder were found effective. Ramayallareddy (2002) found that integrated use of $T$. viride, $P$. fluorescens, neem cake and thiram for seed treatment of groundnut improved seed yield and controlled soil microflora viz., A. niger, Alternaria spp, Curvularria sp, Fusarium spp, Penicillium sp, R. stolonifer, R. solani, S. rolfsii and Verticillium sp. Arunasri (2003) reported that seedling root dip in thiram @ 0.1 per cent + seedling root dip in Trichoderma suspension $\left(\mathrm{T}_{1}\right)+$ seedling root dip in Pseudomonas spp. $\left(\mathrm{B}_{1}\right)$ reduced the $S$. rolfsii incidence in Crossandra to about 6.66 per cent compared to control $(73.66 \%)$.

\section{CONCLUSIONS}

Stem rot caused my Sclerotium rolfsii sacc is one of the most important diseases affecting groundnut crops all over world. Presently, greater emphasis has been replaced with biological control, in order to reduce the environmental hazards, to avoid the development of resistant strains and to reduce the cost of cultivation. Combination with biocontrol agents and fungicides was effective against suppressing the pathogen rather than following only the chemical control. 


\section{REFERENCES}

1. Anitha Chowdary, K. (1997). Studies on sclerotial wilt of bell pepper (Capsicum annum L.). M.Sc (Ag.) Thesis submitted to Acharya N.G. Ranga Agricultural University, Hyderabad.

2. Adhilakshmi, M. P., Latha, V., Paranidharan, D., Balachandar, K., Ganesamurthy \& R. Velazhahan. M. (2013). Biological control of stem rot of groundnut (Arachis hypogaea L.) caused by Sclerotium rolfsii Sacc. with actinomycetes. Archives of Phytopathology and Plant Protection. 47(3): 298-311.

3. Anahosur, K. H.(2001). Integrated Management of potato sclerotium wilt caused by Sclerotium rolfsii. Indian Phytopathology. 54; 158-166.

4. Ansari, M.M and Agnihotri, S.K. (2000). Morphological, physiological and pathological variations among Sclerotium rolfsii isolates of soybean. Indian Phytopathology. 53: 65-67.

5. Arunasri, P. (2003). Management of collar rot disease of crossandra (Crossandra infundibuliformis (L.) Nees.) incited by Sclerotium rolfsii (Sacc.). M.Sc. (Ag), Thesis submitted to Acharya N.G.Ranga Agricultural University, Hyderabad, Andhra Pradesh.

6. Asghari, M. R and Mayee, C. D. (1991).Comparative Efficacy of Management Practices on Stem and Pod Rots of Groundnut. Indian Phytopathology.44: 328-332.

7. Bhat, M. N. and Srivastva, L. S. (2003). Evaluation of some fungicides and neem formulations against six soil borne pathogens and three Trichoderma spp. in vitro. Plant Disease Research. 18(1): 56-59.

8. Belkar, Y.K and Gade, R.M.(2013). Management of root rot and collar rot of Soybean by antagonistic Microorganism. Journal of Plant Diseases and Science. 8(1): 39-42.

9. Bhatia, S.D., R.C and Maheswari, D.K. (2005). Enhancement of plant growth and suppression of collar rot of sunflower caused by Sclerotium rolfsii through Fluorescent Pseudomonas. Indian Phytopathogy. 58: 17-24.

10. Biswas, K.K and Sen, C. (2000). Management of stem rot of groundnut caused by Sclerotium rolfsii through Trichoderma harzianum. Indian Phytopathology. 53: 290-295.

11. Charitha Devi, M and Reddy, M.N (2003). Biological Control of Sclerotium rolfsii the Incitant of Root Rot of Groundnut (Arachis hypogaea L.).National Seminar on Stress Management in Oilseeds For Attaining Self Reliance in Vegetable Oil Indian Society of Oilseeds Research, Directorate of Oilseeds Research, Hyderabad.pp. 18-19.

12. Chanutsa, N., Phonkerd, N and Bunyatratchata, W.(2014). Potential of Pseudomonas Aeruginosa to Control Sclerotium rolfsii Causing Stem Rot and Collar rot Disease of Tomato. Journal of Advanced Agricultural Technologies. 1(2):132-135.

13. Chet, I. (1975).Ultra Structural Basis of Sclerotial Survival in Soil. Microbial Ecology. 2:194-200.

14. Das, B.C., Das, B.K., Dutta, P and Sarmah, D.K. 2006. Bioformulation of Trichoderma harzianum Rifai for management of soybean stem rot caused by Rhizoctonia solani Kuhn. Journal of biological control. 20(1): 57-64.

15. Deepika, S., Tewari, A.K and Dinesh, R. (2014). Invitro antagonistic assessment of T.harzianum PBT 23 against plant pathogenic fungi. Journal of Microbiology and Biotechnology Research. 4(3):59-65.

16. Dutta, B.K. and Deb, P.R., (1986). Effect of organic and inorganic amendments on the soil and rhizosphere microflora in relation to the biology and control of Sclerotium rolfsii causing foot rot of soybean. Leitschift far pfta zenkrankheiten und Pflanzenschutz. 93: 163-171.

17. Durga Prasad, S. (2008). Genetic diversity and biological control of Sclerotium rolfsii (Sacc.) causing stem rot of groundnut 
(Arachis hypogea L.) M.Sc. (Ag.), Thesis submitted to Acharya N.G.Ranga Agricultural University, Hyderabad, Andhra Pradesh.

18. Domsch, K. H. (1980).Compendium of Soil Fungi, Academic Press, London.

19. Farr, D. F., Bills, G. F., Chamuris, G. P and Rossman, A. Y.(1989). Fungi on Plants and Plant Products in the United States. Americanphytopathology Society. pp.1252.

20. Frealin, S. D. (1973). Pest control in groundnuts. Pans manual No. 2 center for over seas research, UK. pp-39-42.

21. Gerrett, S.D. (1956). Biology of root infacting fungi. Cambridge University Press, London, p.293.

22. Gaur, R.B., Sharma, R.N., Sharma, R.R and Vinod Singh Gautam. (2005). Efficacy of Trichoderma for Rhizoctonia root rot control in chickpea. Journal of Mycology and Plant Pathology. 35: 144-150.

23. Harinath Naidu. (2000). Crossandra - a new host record for Sclerotium rolfsii. Indian Phytopathology. 53: $496: 497$.

24. Gupta, S.K and Ashu Sharma. (2004). Symptomology and management of crown rot (Sclerotium rolfsii) of French bean. Journal of Mycology and Plant Pathology. 34: 820-823.

25. Harman, G.E and Kubicek, C.P. (Eds) (1998) Trichoderma and Gliocladium, Vol. 1 \& 2 Taylor and Francis, London.

26. Johnson, M and Reddy, P.N and Reddy, D.R. (2008). Comparative efficacy of rhizosphere mycoflora, fungicides, insecticides and herbicides against groundnut stem rot caused by Sclerotium rolfsii. Annals of Plant Protection Sciences, 16 (2):414-418.

27. Krishnakaknth, A., Gowda, M. V. C and Motagi, B. N. (1999). Response of spanish groundnuts to stem and pod rots caused by Sclerotium rolfsii Sacc. International Arachis Newsletter 19: 27-28.

28. Kapadiya, I. B., Akbari, L. F., Siddhapara, M. R. and Undhad, S. V. (2013). Evaluation of fungicides and herbicides against the root rot of okra. The Bioscan. 8(2): 433-436.

29. Kajal Kumar, B and Chitreswar sen. (2000). Management of stem rot of groundnut caused by Sclerotium rolfsii through Trichoderma harzianum. Indian Phytopathology. 53: 290-295.

30. Laha, G.S., Verma, J.P and Singh, R.P. (1996).Effectiveness of Fluorescent pseudomonads inthe management of sclerotial wilt of cotton. Indian Phytopathology. 46: 3-8.

31. Madhuri, V and Narayan Reddy, P. (2013). Compatibility of herbicides with fungicides against S. rolfsii, R. solani and F.udum. Bioinfolet. 10 (3B): 1032-1036.

32. Madhuri,V and Sagar,G.K.(2016).Screening of fungicides and herbicides against sclerotium rolfsii, stem rot of groundnut under in vitro conditions.3(6):125-133.

33. Maiti, D and Sen, C. (1985). Integrated biological control of Sclerotium rolfsii with nitrogenous fertilizers and T. harzianum. Indian Journal of Agricultural Sciences.55: 464-468.

34. Manjula, K., Krishna Kishore, A., Girish, G and Singh, S.D.(2004).Combined application of Pseudomonas fluorescens and Trichoderma viride has an Improved Biocontrol Activity Against Stem Rot in Groundnut. The Plant Pathology Journal. 20(1): 75-80.

35. Manyar, A.V., Khandelwal, S.R., Chaudhari, B.L., Meyer, J.M. and Chincholkar, S.B.(2004). Siderophore production by a marine Pseudomonas aeruginosa and its antagonistic action against phytopathogenic fungi. Applications of Biochemistry and Biotechnology. 118(1-3):243-251.

36. Mayee, C. D. and Datar, V. V. (1988). Diseases of groundnut in the tropics. Review of Tropical Plant Pathology. 5: 85-118. 
37. Mcmilan, W.D., Christie, J.R. and Horn, N.L. (1949). Efficacy of soil fumigants as affected by soil temperature and moisture. Phytopathology. 39: 272-283.

38. Mehan,V. K., Mayee, C. D., Mcdonald, D., Ramakrishna, N and Jayanthi, S. (1995).Resistance in Groundnut to Sclerotium rolfsii Caused Stem and Pod Rots. International Journal of Pest Management. 41:79-82.

39. Mehrotra,R. S and Aneja, K. R. (1990). An Introduction to Mycology. Wilen Eastern Limited, New Delhi. pp. 776.

40. Muthamilan, M and Jeyarajan, R.(1992). Effect of antagonistic fungi on sclerotium rolfsii causing root rot of groundnut. Journal of Biological Control. 6(2): 88-92.

41. Narasimha Rao, S. (2000). Biological control of wilt of potato caused by Sclerotium rolfsii Sacc. M.Sc. (Agri.) thesis, University of Agricultural Sciences, Dharwad, pp - 41- 42.

42. Narayana Bhat and Srivastava, L.S (2003). Evaluation of some fungicides and neem formulations against six soil-borne pathogens and three Trichoderma spp in vitro. Plant Disease Research. 18:56-59.

43. Pant, $R$ and Mukhopadhyay, A.N. (2001). Integrated management of seed and seedling rot complex of soybean. Indian Phytopathology. 54: 346-350.

44. Pastro, S and March, G.J. (1999). In vitro effect of residual herbicides used in peanut on Sclerotium rolfsii. Fitopatologia.34 (3): 116-121.

45. Patil, R.P., Jagadessh, K.S and Kulkarni, J.H.(1998). Isolation of Fluorescent Pseudomonads associated with roots of different plants and their in vitro antagonism against groundnut collar rot pathogen Sclerotiun rolfsii (Sacc.). Karnataka Journal of Agricultural Sciences. 11: 45-49.

46. Patibanda, A.K., Upadhyay, J.P. Mukhopadhyay, A.N.(2002). Efficacy of Trichoderma harzianum Rifai alone or in combination with fungicides against Sclerotium wilt of groundnut. Journal of Biological Control. 16(1): 57-63

47. Prasad, R.D., Rangeshwaran, $R$ and Sree Ramakumar.(1999). Biological control of root and collar rot of sunflower. Journal of Mycology and Plant Pathology. 29: 184-187.

48. Pranab Dutta and Das B.C. (2002).Management of Collar Rot of Tomato by Trichoderma Spp and Chemicals. Indian Phytopathology. 55:235-237.

49. Punja, Z.K. 1985. Sclerotium (Athelia) rolfsii, a pathogen of many plant species. In advances in plant pathology (G.S. Sindhu, ed.). Academic Press, San Diego, C.A. pp.523-534.

50. Podile, A. R and Dube, H. C. (1988). Fluorescent pseudomonads and Bacillus subtilis as plant growth promoting rhizobacteria. In: International conference on Research in plant science and its relevance to future. March 7-11, 1988, Delhi (Abstract). 80p

51. Radhaiah A.(2012).Biocontrol potential of indigenous pseudomonas spp. against Sclerotium rolfsii causing stem rot of groundnut. International Journal of Food, Agriculture and Veterinary Sciences.2 (1) :134 -141.7.

52. Rajani, T., Eswara Reddy, N.P and Hariprasad Reddy, K. (2006). Effect of organic amendments and Trichoderma viride on population density of Sclerotium rolfsii (Sacc.) incident of stem rot groundnut. Geobios. 33: 45-48.

53. Rakholiya, K.B and Jadeja, K.B. (2010). Effect of seed treatment of biocontrol agents and chemicals for management of stem and pod rot of groundnut. International Journal of Plant Protection. 3(2) : 276-278.

54. Rakh, R. R (2011). Biological control of Sclerotium rolfsii, causing Stem rot of Groundnut by Pseudomonas Cf Monteilii 9. Recent Research in Science and Technology. 3(3):26-34. 
55. Ramarao, P and Usharaja. (1980). Effect of soil moisture on development of foot and root rot of wheat and on through soil microflora. Indian Journal of Mycology and Plant Pathology. 10: 17-22.

56. Rama Yalla Reddy, M. (2002). Evaluation of certain bio-fungicides against predominant seed borne fungal disease of groundnut (Arachis hypogaea L.). M.Sc.(Ag.) Thesis submitted to Acharya N.G.Ranga Agricultural University, Hyderabad (A.P.).

57. Rao, N., S., Anahosur, K.H and Kulkarni, S. 2004. Eco-friendly approaches to management of wilt of potato (Sclerotium rolfsii). Journal of Mycology and Plant pathology. 34: 327-329.

58. Reddy, P. S. (1992).Groundnut situation in India, NRCG, Workshop cum Seminar on Groundnut. Production Technology, Advanced Centre of Training (Oilseeds), G. A. U., Junagadh.

59. Raoof, M.A., Rama Bhadra Raju and Mehtab Yasmeen. (2006). Biocontrol potential and shelf life of Trichoderma viride for the management of castor wilt. Indian Journal of Plant Protection. 34: 75-80.

60. Rolfs, P.H. (1892). Tomato blight: some hints. Bulletin Fla. Agric. Experimentation Station, p.18.

61. Rosenblueth, M and Martínez-Romero,E.(2006). Bacterial Endophytes and Their Interactions with Hosts. The American Phytopathological Society.19(8):827-837.

62. Rout, M. K., Mishra, B. and Sethy, M.( 2006). In vitro evaluation of agrochemicals, plant extracts and biological antagonists against sclerotial wilt of sunflower caused by Sclerotium rolfsii. Journal of Mycopathological Research. 44(2): 263-265.

63. Saccardo, P.A.(1911). Notae Mycological. Annales Mycologici. 9: 249-257.

64. Saralamrna,S and Vithal Reddy, T. (2003).Integrated Management of Sclerotial Root Rot in Groundnut. National Seminar on Stress Management in Oilseeds For Attaining Self Reliance in Vegetable Oil Indian Society of Oilseeds Research, Directorate of Oilseeds Research.Hyderabad.pp. 20 - 21.

65. Schulz, B., Boyle, C. (2005). The endophytic continuum. Mycological Research. 109: 661-686.

66. Seshakiran, K., (2002). Use phytochemicals in the management of stem rot of groundnut caused by Sclerotium rolfsii Sacc. M.Sc.(Agri.) Thesis, University of Agricultural Sciences, Dharwad.

67. Singh, K.K. and Dwivedi, R.S., (1990). Fungicidal properties of neem and blue gum against Sclerotium rolfsii Sacc. Foot rot pathogen of barley. Acta Botanica Indica. 18: 260- 262.

68. Singh, R.K. and Dwivedi, R.S., (1989). Effect of plant parts/products on morphology and growth of Sclerotium rolfsii Sacc. A footrot pathogen of barley. Acta Botanica Indica, 17: 125-129.

69. Singh, S.P., Singh, H.B and Singh, D.K.(2013). Trichoderma harzianum and Pseudomonas sp.mediated management of sclerotium rolfsii rot in tomato (Lycopersicon esculentum Mill.) The Bioscan.8(3): 801-804.

70. Srikant Das and Raj, S.K. (1995). Management of root rot of sugarbeet (Beta vulgaris) caused by Sclerotium rolfsii in field through fungicides. Indian Journal of Agricultural Sciences. 65 (7): 543-546.

71. Subramanian, K.S. (1964). Studies on Sclerotial Root Rot Disease of Groundnut (Arachis hypogea.L) By Sclerotium rolfsii Sacco.Madras Agricultural Journal.51: 367-378.

72. Sunkad, G. (2012).Tebuconazole: a new triazole fungicides molecule for the management of stem rot of groundnut caused by Sclerotium rolfsii. The Bioscan. 7(4): 601-603.

73. Torray, N. K., Verma, K. P. and Sinha, A. K. (2007). Evaluation of fungicides and bio-agents against Sclerotium rolfsii Sacc. causing collar rot disease of chickpea in laboratory and field condition. Advances in Plant Sciences. 20(2): 439-442. 
74. Tripathi, S.K., Sathie, K.B and Vyas, S.C.(1988). Chemical control of collar rot of pea. Indian Phytopathology. 41(1): 143144.

75. Uma singh and Thapliyal, P.N. (1998). Effect of inoculums density, host cultivars and seed treatment on the seed and seedling rot of soybean caused by Sclerotium rolfsii. Indian Phytopathology. 51 (3): 244-246.

76. Uma Maheswari, M.P., Muthuswamy, M and Alice, D. 2002. Evaluation of antagonists against jasmine wilt caused by Sclerotium rolfsii (Sacc.). Journal of Biological Control. 16: 135-140.

77. Upadhyay, J.P and Mukhopadhyay, A.N. (1986). Biological control of Sclerotium rolfsii by Trichoderma harzianum of sugarbeet. Tropical Pest Management. 215-220.

78. Vanitha,S and Suresh, M. (2002).Management of Collar Rot of Brinjal (S. rolfsii) by Nonchemical Methods. South Indian Horticulture.50:602-606.

79. Varadharajan Karthikeyana (2007). Biological control of groundnut stem rot caused by Sclerotium rolfsii (sacc). Archives of Phytopathology and Plant Protection. pp. 239-246.

80. Vinod Dange. (2006). Studies on Root Rot of Chilli Caused By Sclerotium rolfsii Sacc.Thesis Submitted to the University of Agricultural Sciences, Dharwad.

81. Vyas, S.C., Mushtaq Ahmed Reeti Singh., Shastry, P.P., Ahmed, M and Singh, R. (1986a). Suppression of soil borne pathogens of soybean in vitro and in vivo by herbicides. Indian Phytopathology. 39 (3): 35-399.

82. Ziedan, E.H.E. (2006). Manipulating endophytic bacteria for biological control to soil borne diseases of peanut. Journal of Applied science Research. 2: 497-502.

83. Wood, R.K.S and Tveit, M.(1955). Control of plant diseases by antagonistic micro organisms. Botany Review. 21: $441-492$. 
